\title{
Review on Phase Behavior in Tight Porous Media and Microscopic Flow Mechanism of $\mathrm{CO}_{2}$ Huff-n-Puff in Tight Oil Reservoirs
}

\author{
Yong Tang, ${ }^{1}$ Jiehong Tang, ${ }^{1}$ Qi Liu, ${ }^{2}$ Yong Wang $\mathbb{D}^{1},{ }^{1}$ Zigang Zheng, ${ }^{3}$ Yingjie Yuan, \\ and Youwei $\mathrm{He}^{\mathrm{l}}$ \\ ${ }^{1}$ State Key Laboratory of Oil and Gas Reservoir Geology and Exploitation, Southwest Petroleum University, Chengdu, \\ Sichuan 610500, China \\ ${ }^{2}$ Chuanqing Drilling Engineering Co., Ltd., CNPC, Chengdu, Sichuan 610051, China \\ ${ }^{3}$ Research Institute of Petroleum Exploration \& Development, Changqing Oilfield Company, PetroChina, Xi'an, \\ Shaanxi 710018, China
}

Correspondence should be addressed to Yong Wang; wangyonget@163.com

Received 21 August 2020; Revised 10 October 2020; Accepted 24 October 2020; Published 7 November 2020

Academic Editor: Jinze Xu

Copyright (C) 2020 Yong Tang et al. This is an open access article distributed under the Creative Commons Attribution License, which permits unrestricted use, distribution, and reproduction in any medium, provided the original work is properly cited.

\begin{abstract}
The successful development of tight oil reservoirs in the U.S. shows the bright future of unconventional reservoirs. Tight oil reservoirs will be the main target of exploration and development in the future, and $\mathrm{CO}_{2}$ huff-n-puff is one of the most important methods to enhance oil recovery factor of tight oil reservoirs in North America. To improve the performance of $\mathrm{CO}_{2}$ huff-n-puff, injection and production parameters need to be optimized through numerical simulation. The phase behavior and microscopic flow mechanism of $\mathrm{CO}_{2}$ huff-n-puff in porous media need to be further investigated. This paper presents a detailed review of phase behavior and microscopic flow mechanism in tight porous media by $\mathrm{CO}_{2}$ huff-n-puff. Phase behavior in tight porous media is different from that in a PVT cylinder since the capillary pressure in tight porous media reduces the bubble point pressure and increases the miscibility pressure and critical temperature. The condensate pressure in tight porous media and nonequilibrium phase behavior need to be further investigated. The microscopic flow mechanism during $\mathrm{CO}_{2}$ huff-n-puff in tight porous media is complicated, and the impact of molecular diffusion, gas-liquid interaction, and fluid-rock interaction on multiphase flow is significant especially in tight porous media. Nuclear magnetic resonance (NMR) and molecular simulation are efficient methods to describe the microscopic flow in tight oil reservoirs, while the NMR is not cost-effective and molecular simulation needs to be improved to better characterize and model the feature of porous media. The improved molecular simulation is still a feasible method to understand the microscopic flow mechanism of $\mathrm{CO}_{2}$ huff-n-puff in tight oil reservoirs in the near future. The microscopic flow model in micropore network based on digital core is worth to be established, and phase behavior needs to be further incorporated into the microscopic flow model of $\mathrm{CO}_{2}$ huff-n-puff in tight porous media.
\end{abstract}

\section{Introduction}

The depletion of conventional oil resources makes it hard to meet the requirement of human activity and industry, and unconventional oil reservoirs (e.g., tight oil, shale oil) have become the significant sources of energy supplement [1-5]. Tight oil reservoirs have been considered as the most promising resources among unconventional oil reservoirs. At present, the main method to exploit tight oil reservoirs is primary depletion after massive hydraulic fracturing along long horizontal wells, but the primary recovery factor is only $5 \% \sim 10 \%$
[6-10]. Successful development of tight oil reservoirs has been achieved in North America (e.g., Bakken Basin, Permian Basin, and Eagle Ford) by using $\mathrm{CO}_{2}$ huff-n-puff [11-17].

$\mathrm{CO}_{2}$ huff-n-puff has several advantages for improving the oil recovery of tight oil reservoirs. Firstly, compared with waterflooding, $\mathrm{CO}_{2}$ molecules can enter into the micro pores more easily at the same injection pressure and $\mathrm{CO}_{2}$ huff-npuff can avoid water-sensitive effects. Secondly, low miscibility pressure of $\mathrm{CO}_{2}$ in crude oil makes it easy to achieve miscible state, which reduces the viscosity of crude oil [18-20]. Thirdly, the consumption volume of $\mathrm{CO}_{2}$ is relatively small, and the oil 
increment is significant [21, 22]. Ma et al. [23] conducted physical simulation experiments of $\mathrm{CO}_{2}$ huff-n-puff and $\mathrm{N}_{2}$ huff-n-puff in tight oil core. The results showed that the oil recovery factor of through $\mathrm{CO}_{2}$ huff-n-puff is about five to eight times higher than that of primary depletion, and the cumulative oil recovery factor of tight oil core through $\mathrm{CO}_{2}$ huff-n-puff is higher than that through $\mathrm{N}_{2}$ huff- $n$-puff.

$\mathrm{CO}_{2}$ huff-n-puff has attracted extensive attention in recent years. On the one hand, numerical simulation has been performed to optimize injection and production parameters [24-26]. On the other hand, physical experiments have been conducted to investigate the phase behavior and microscopic flow mechanism to improve the $\mathrm{CO}_{2}$ huff-n-puff performance in tight oil reservoirs [27]. The phase behavior in a PVT cylinder is different from that in porous media. Previous studies about phase behavior in tight porous media are mainly based on the principle of flash equilibrium [28]. Recently, gas breakthrough has been observed for $\mathrm{CO}_{2}$ huff-n-puff in tight oil reservoirs. NMR and molecular simulation are used to investigate this. In addition, core experiments, mathematical models, etc. are used, which provide new ways for the study.

This paper firstly reviews the mechanism and dominated factors of enhancing oil recovery by $\mathrm{CO}_{2}$ huff-n-puff. Then, it presents a detailed review of phase behavior and gives the achievements of microscopic flow mechanism in tight porous media by $\mathrm{CO}_{2}$ huff-n-puff through different research methods.

\section{Mechanism and Dominated Factors of Enhancing Oil Recovery by $\mathrm{CO}_{2}$ Huff-n-Puff}

2.1. Mechanism of Enhancing Oil Recovery through $\mathrm{CO}_{2} \mathrm{Huff}-$ $n$-Puff. Studies on the main mechanism of enhancing oil recovery through $\mathrm{CO}_{2}$ huff-n-puff in tight oil reservoirs are dominated from Bakken basin in the U.S. $[1,11,12] . \mathrm{CO}_{2}$ huff-n-puff is implemented in Bakken tight oil reservoirs after massive hydraulic fracturing. $\mathrm{CO}_{2}$ transports in the fracture network firstly (see Figure 1(a)) and then infiltrates into the matrix. Meanwhile, some crude oil is pushed into the deep matrix by $\mathrm{CO}_{2}$ (see Figure 1(b)). The expansion of $\mathrm{CO}_{2}$ after $\mathrm{CO}_{2}$ enters the matrix allows some of the crude oil in the matrix to flow into the fracture. There are also differences of gradient mass or concentration of $\mathrm{CO}_{2}$ and light components in the oil and gas phase during the $\mathrm{CO}_{2}$ huff and soaking stage. $\mathrm{CO}_{2}$ moves from the gas phase to the oil phase, while light components move from the matrix to the fractures [29] (see Figure 2). $\mathrm{CO}_{2}$ completely penetrates into the matrix and mixes with crude oil as soaking time increases. More oil flow into the fractures with the further expansion of $\mathrm{CO}_{2}$. The reinflation of $\mathrm{CO}_{2}$ pushes crude oil from the matrix flowing towards the fractures with the decrease of reservoir pressure caused by oil production. The functions of $\mathrm{CO}_{2}$ huff-n-puff are mainly reflected in the injection stage (pressure supplement), the soaking stage (the dissolution and diffusion), and the production stage (the dissolved gas driving) [30].

The testing analysis of crude oil from YP1-7 well in Fuyu oilfield indicated that the injected $\mathrm{CO}_{2}$ changed the physical properties of crude oil. The light components are increased after $\mathrm{CO}_{2}$ huff-n-puff, while the heavy components are reduced. The viscosity of surface crude oil decreases by $50.7 \%$, which enhances the flow ability of crude oil. The functions of $\mathrm{CO}_{2}$ huff-n-puff in Fuyu tight oil reservoir are mainly reflected in the extraction on heavy components of crude oil, the viscosity reduction during miscibility, and the enhancement of the formation permeability [32].

$\mathrm{CO}_{2}$ is also suggested for the exploitation of heavy oil reservoirs in EOR [33]. Jia et al. [34] points that bubbles appear and then been wrapped by resin and asphaltene, which forms the semisolid membrane. The membrane prevents bubble growing into a continuous phase, so "foamy oil" forms at this time. Viscosity of crude oil is obviously decreased, which contributes a lot to a high oil recovery factor [35].

A lot of the parameters (e.g., injection pressure, injection rate, fracture length, soaking pressure, and time of each cycle) are optimized by numerical simulations after understanding the physical mechanism of $\mathrm{CO}_{2}$ huff-n-puff in tight oil reservoirs.

2.2. Dominated Factors for $\mathrm{CO}_{2} \mathrm{Huff-n-Puff}$ in Tight Oil Reservoirs. Zuloaga et al. [36] established a numerical reservoir simulation model referring to the fluid and formation data from middle Bakken formation. It was found that the incremental oil recovery factor of tight oil reservoir by $\mathrm{CO}_{2}$ huff-n-puff is higher than that of $\mathrm{CO}_{2}$ flooding when the permeability is lower than $0.03 \mathrm{mD}$ (see Figure 3 ). $\mathrm{CO}_{2}$ flooding is preferred when formation permeability exceeds $0.03 \mathrm{mD}$.

Sun et al. [37] simulated $\mathrm{CO}_{2}$ huff-n-puff after fracturing in horizontal wells of middle Bakken oilfield by using the embedded discrete fracture model. The results suggested that $\mathrm{CO}_{2}$ diffusivity had a greater influence on oil production than the number of cycles, injection time, etc. (see Figure 4). Jia et al. [1] built a CMG-GEM model based on the geological and PVT data from Bakken formation, and found that molecular diffusion plays a significant role for enhancing oil recovery factor. A maximum of 39\% underestimation of oil recovery will be caused if molecular diffusion is ignored in the study.

Wang [38] pointed out that the properties of crude oil under formation condition became better, and its saturation pressure and volume coefficient are increased with the increase of $\mathrm{CO}_{2}$ injection volume. The degree of reserve recovery becomes greater with the increase of the soaking pressure (Figure 5), but the $\mathrm{CO}_{2}$ consumption per unit of oil production also becomes higher. The low viscosity of crude oil and the long soaking time contribute a lot to the final recovery factor of the tight oil reservoir through $\mathrm{CO}_{2}$ huff-n-puff.

Yang et al. [39] simulated the $\mathrm{CO}_{2}$ huff-n-puff in a tight oil reservoir by means of physical simulation experiment. The final recovery factor of $\mathrm{CO}_{2}$ huff-n-puff is $12.5 \%$ higher than that of elastic production. The tight oil reservoirs in Xinjiang show medium to strong water sensitivity. To improve the tight oil recovery factor after depletion development, Ma et al. [23] carried out a physical simulation experiment of $\mathrm{CO}_{2}$ huff-n-puff in the laboratory. The analyses show that more depletion energy is released by dissolved 


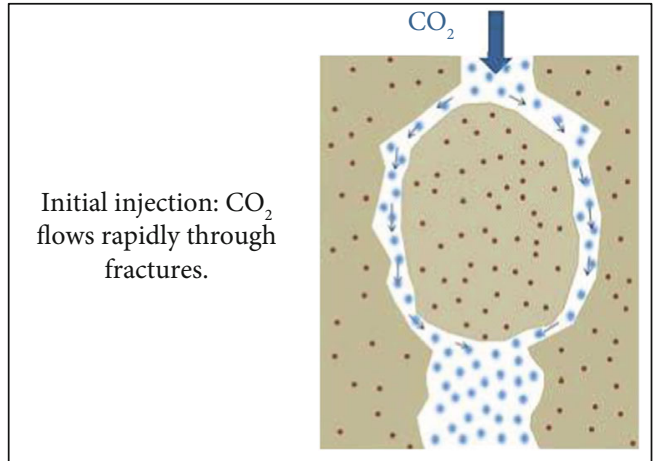

(a)

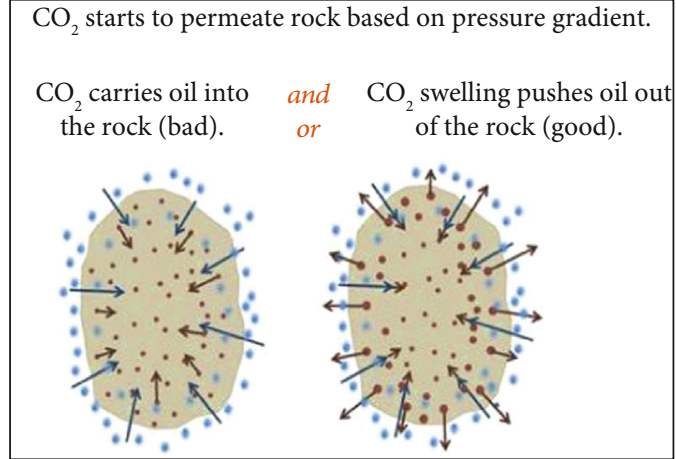

(b)

FIgURE 1: Two stages of $\mathrm{CO}_{2}$ huff-n-puff process in fractured tight oil reservoir [31].

\begin{tabular}{|r|ll|}
\hline \multicolumn{1}{|c|}{$\begin{array}{c}\text { Matrix } \\
\text { Oil }\left(\mathrm{C}_{1}, \mathrm{C}_{2}, \mathrm{C}_{3}, \ldots\right)\end{array}$} & \multicolumn{1}{c|}{$\begin{array}{c}\text { Fracture } \\
\text { Gas }\left(\mathrm{CO}_{2}=1\right)\end{array}$} \\
$J_{\mathrm{CO}_{2}}$, oil & $J_{\mathrm{CO}_{2}}$, gas \\
$J_{\mathrm{C}_{1}}$, oil & $J_{\mathrm{C}_{1}}$, gas \\
$J_{\mathrm{C}_{2}}$, oil & $J_{\mathrm{C}_{2}}$, gas \\
$J_{\mathrm{C}_{3}}$, oil & & \\
\hline
\end{tabular}

Figure 2: Mass transfer between oil and gas [29].

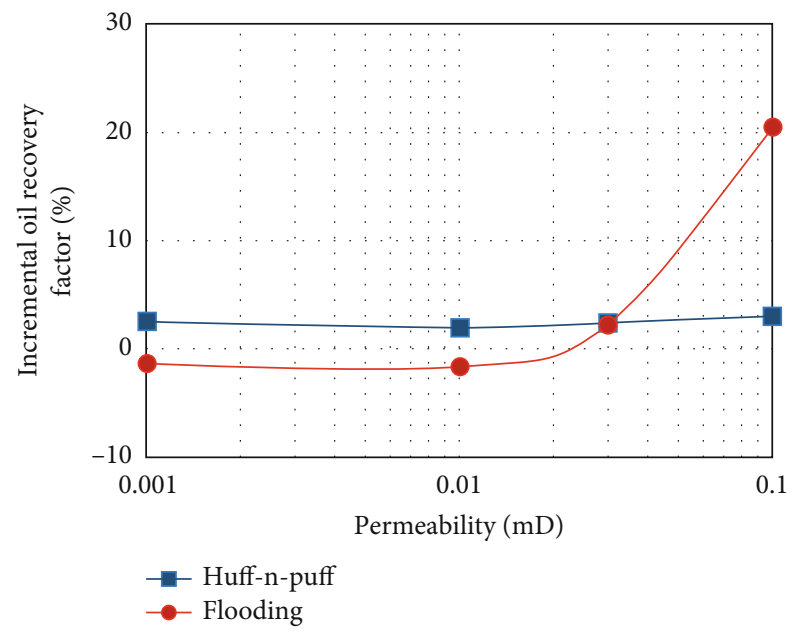

FIGURE 3: Comparison of incremental oil recovery factor between $\mathrm{CO}_{2}$ flooding and $\mathrm{CO}_{2}$ huff-n-puff for the range of permeability from $0.001 \mathrm{mD}$ to $0.1 \mathrm{mD}$ [36] (it was calculated by subtracting the oil recovery factor of base case without $\mathrm{CO}_{2}$ injection).

$\mathrm{CO}_{2}$ expansion with a lower the production pressure, which results in a higher oil production and a greater cumulative recovery factor. The cumulative recovery factor of $\mathrm{CO}_{2}$ huffn-puff is increased by $16 \% \sim 34 \%$, which is about five to eight times of the recovery factor by primary depletion (see Figure 6).

Liu [40] carried out laboratory experiments and field tests for Gaotaizi tight oil reservoir in Songliao Basin. The results showed that $\mathrm{CO}_{2}$ huff-n-puff has good adaptability and is an effective measure to improve the recovery factor of tight oil reservoirs. The parameters $\left(\mathrm{CO}_{2}\right.$ huff-n-puff time, injection rate, total injection volume, soaking time, and production flow pressure) were optimized to provide references for the production based on the evaluation of oil increment and oil exchange rate and the production dynamic analysis. In addition, parameters need to be optimized including periodic injection volume, injection pressure, and soaking pressure [29]. Ma et al. [41] found that injecting $0.1 \mathrm{PV} \mathrm{CO}_{2}$ in the first cycle and carrying three cycles is the optimal economic scheme through the core experiment of Ordos tight oil reservoir. The scheme can improve the recovery factor up to $34.65 \%$.

The above numerical simulations and experiments show that $\mathrm{CO}_{2}$ huff-n-puff is a feasible technology to improve the recovery factor of tight oil reservoirs. Soaking time and $\mathrm{CO}_{2}$ diffusivity are two dominated factors for $\mathrm{CO}_{2}$ huff-npuff in tight oil reservoirs. The phase behavior in tight porous media and microscopic flow mechanism plays an important role in updating of engineering software, so the difference of phase behavior and microscopic flow mechanism in tight porous media cannot be ignored in the numerical simulations.

\section{Phase Behavior in Tight Porous Media}

The effect of tight porous media on fluid phase behavior cannot be ignored. Recently, theoretical studies are carried out on phase behavior in tight porous media, which mainly base on the principle of flash equilibrium and consider factors such as capillary pressure, adsorption of hydrocarbons on the surface of porous media, migration of critical parameters for hydrocarbon components, and pore structure distribution of porous media [28, 42].

It is necessary to consider the wall effect of the pores, including the influence of capillary pressure and adsorption when simulating PVT experiments of shale oil. The oil recovery factor is reduced due to the adsorption of heavy oil recombination on the pore wall [43]. Lemus et al. [43] pointed that bubble point pressure will decrease because of capillary pressure. Nojabaei et al. [44] considered the effect of small pores on bubble point pressure and dew point pressure. The calculated three curves with different pore sizes indicate that the bubble point pressure decreases as the pore 


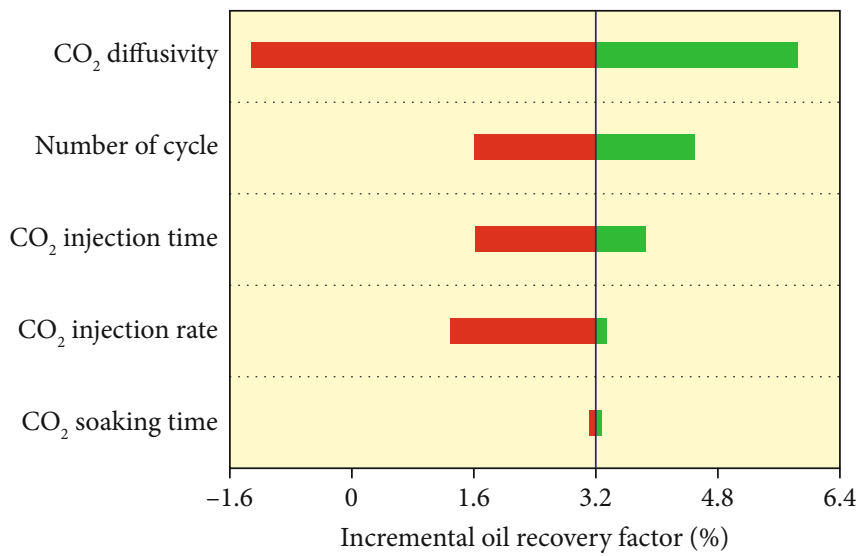

FIGURE 4: Rank of impacts of five uncertain parameters on incremental oil recovery factor [37].

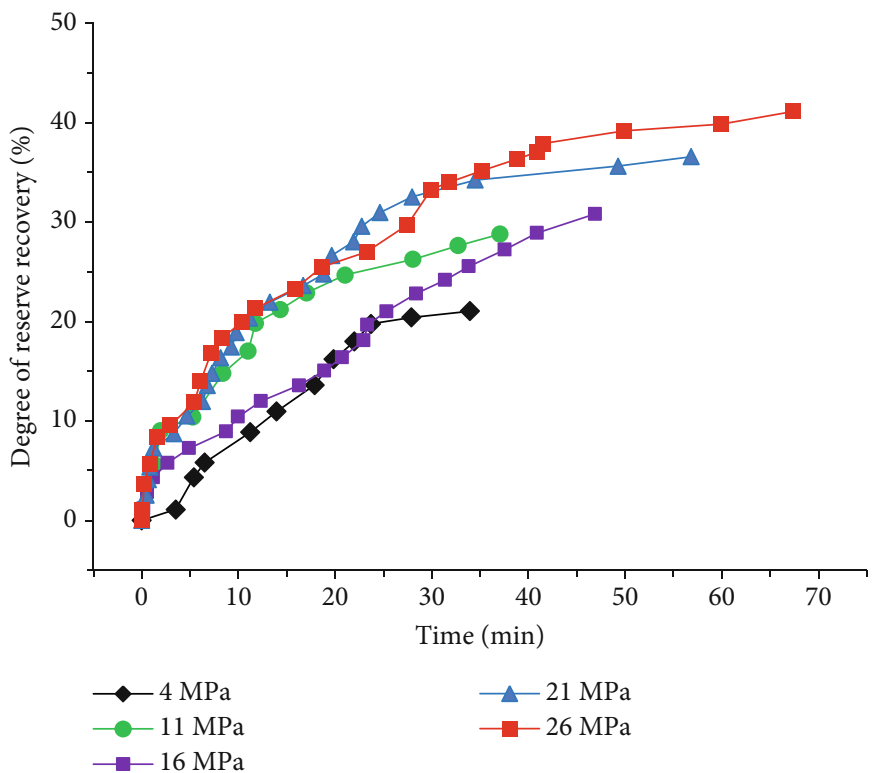

Figure 5: The relationship between degree of reserve recovery and time under different soaking pressure [38].

size is becoming smaller, especially at the lower temperature (see Figure 7). Besides, the dew point pressure increases if the pressure is greater than that determined at the cricondentherm, but decreases when pressure is lower than calculated at cricondentherm. Yang and Li [45] corrected the effects of molecular-wall interaction and geometric constraints on molecular-wall interaction. They carried out numerical simulation of the natural gas huff-n-puff in middle Bakken formation. The results show that the phase envelope of fluids in the reservoir tends to shrink. Under the condition of reservoir temperature, the bubble point pressure of the middle Bakken oil decreased by $17.32 \%$ considering the confinement effect. Sheng et al. [46] found that the bubble point temperature of crude oil increases with the pore diameter becoming smaller. Pang et al. [47] established a theoretical model to predict bubble point and dew point of oil in tight reservoirs. The calculation results show that the bubble point decreases as permeability becomes poor due to the increase of capillary pressure (see Figure 8(a)). Compared with Nojabaei et al. [44], the method proposed by Pang et al. [47] is more practical because permeability is often used in petroleum industry. Besides, the dew point increases in the upper dew point interval but decreases in the lower dew point interval (see Figure 8(b)). Wu et al. [48] studied $\mathrm{CO}_{2}$ injection in middle Bakken reservoir and found that bubble point pressure and minimum miscibility pressure (MMP) decreased with the increase of pore size. Zhu [49] found that the diffusion rate of oil and gas decreased while the pore size became smaller, and the inflection point pressure of displacement efficiency of n-decane was slightly larger than that of the MMP of the system in the PVT cylinder, which proved the effect of porous media on the MMP of n-decane. Yu et al. [50] studied the impact of injected gas composition on miscibility pressure, and found that the methane and nitrogen increased the miscibility pressure and delay the miscibility or near-miscibility between $\mathrm{CO}_{2}$ and crude oil. 


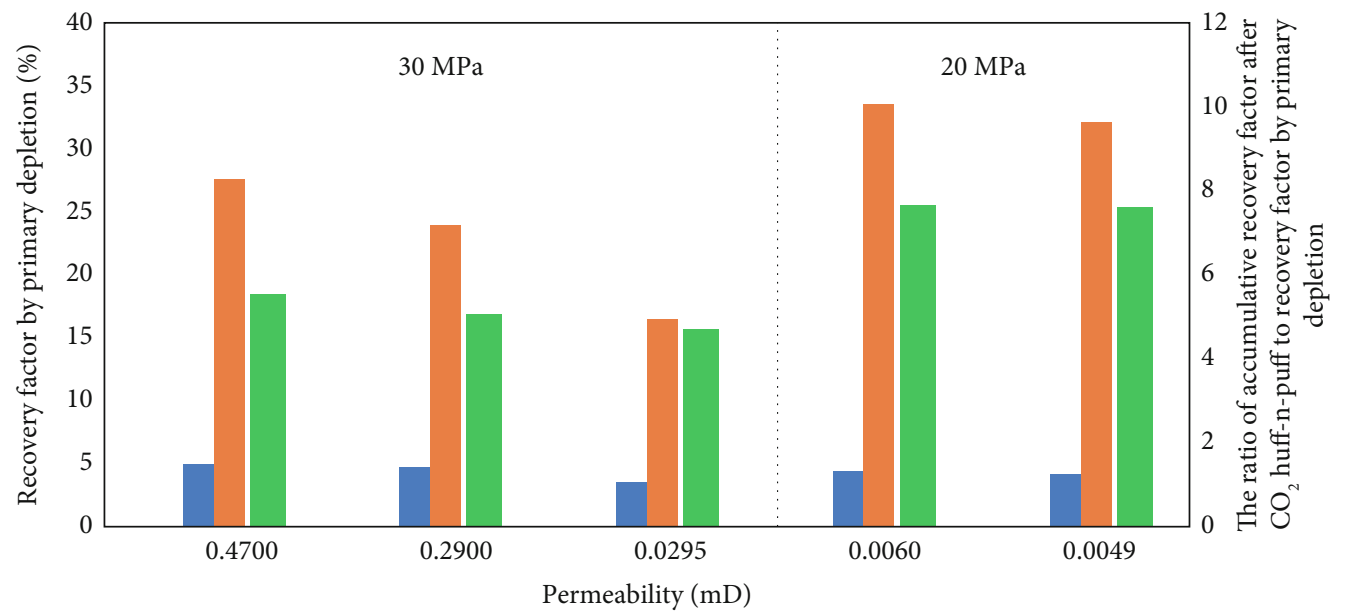

Recovery factor by primary depletion

Accumulative recovery factor after $\mathrm{CO}_{2}$ huff-n-puff

The ratio of accumulative recovery factor after $\mathrm{CO}_{2}$ huff-n-puff to recovery factor by primary depletion

FIGURE 6: Recovery factor of cores with different matrix permeability [23].

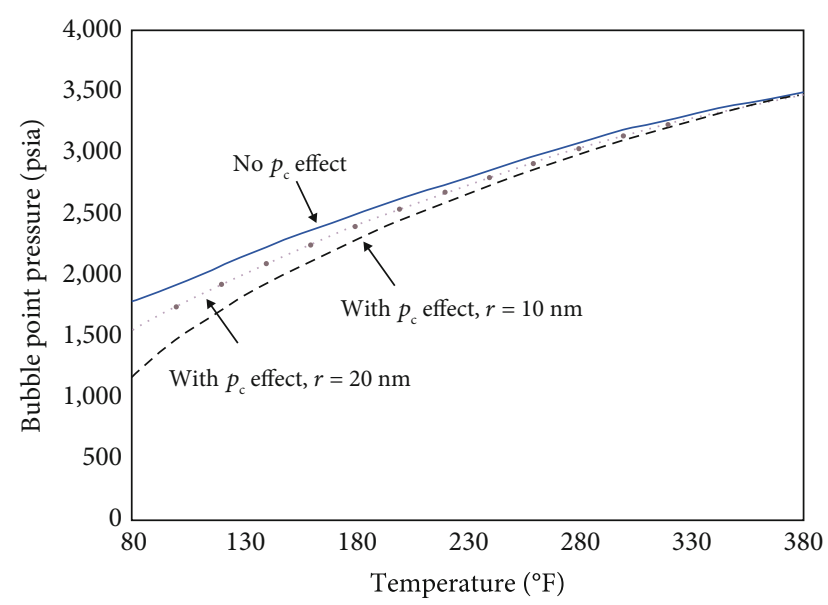

Figure 7: The relationship between bubble point pressure and temperature considering capillary pressure [44].

Studies have shown that the critical temperature and pore size are linearly negatively correlated. The capillary pressure reduces the bubble point pressure and the critical parameters. Jiang [28] compared the PVT experiment and the phase behavior experiment of fluid in porous medium. The bubble point pressure in porous medium was lower than that in the measured value in PVT cylinder after the crude oil was saturated with $\mathrm{CO}_{2}$, and the bubble point pressure reduction increases with the decrease of dissolved $\mathrm{CO}_{2}$ and decrease of the core permeability. The results of phase behavior in tight porous media are summarized in Table 1. Generally, reduction of bubble point pressure, the bubble point temperature, and the MMP increase as permeability of porous media becomes lower.

It is difficult to observe the change of material in tight porous media directly by conventional measurement methods so that noninterventional and visible method is introduced to measure the fluid phase behavior with the advances in experimental instruments [51]. MRI and X-ray CT are the most important noninterventional and visible methods for investigating the phase changes of oil in porous media [52]. Li et al. [51] scanned residual oil in cores after $\mathrm{CO}_{2}$ immiscible flooding and miscible flooding by CT. It was obvious that residual oil saturation in cores after immiscible flooding was significantly higher than that after miscible flooding. Therefore, miscible flooding should be used to improve the recovery factor of tight oil reservoirs. There is an optimal gas injection volume, beyond which the increase of oil recovery factor is little (see Figure 9). In addition, Li et al. [51] also found that increasing $\mathrm{CO}_{2}$ injection rate under miscibility condition had little influence on displacement efficiency. It indicates that when the miscibility pressure is achieved, it almost realizes a first contact miscibility with crude oil in porous media.

Although several important parameters of fluid phase behavior in tight porous media have been studied, the difference of the condensate pressure in the tight porous media from that in a PVT cylinder needs to be studied, which is significant for the development of gas-condensate reservoirs. Nonequilibrium phase behavior and the influence of capillary pressure on phase behavior need to be further investigated to obtain more reliable and accurate results.

\section{Microscopic Flow in Tight Oil Reservoirs}

The microscopic flow of oil and injected gas in tight oil reservoirs has received much attention since the microscopic fluid flow is different from that in conventional reservoirs due to the small pore size [53-55]. Therefore, multiple experimental methods have been used to investigate the microscopic flow mechanism in tight oil reservoirs. At present, NMR experiments, molecular simulations, and other methods have been 


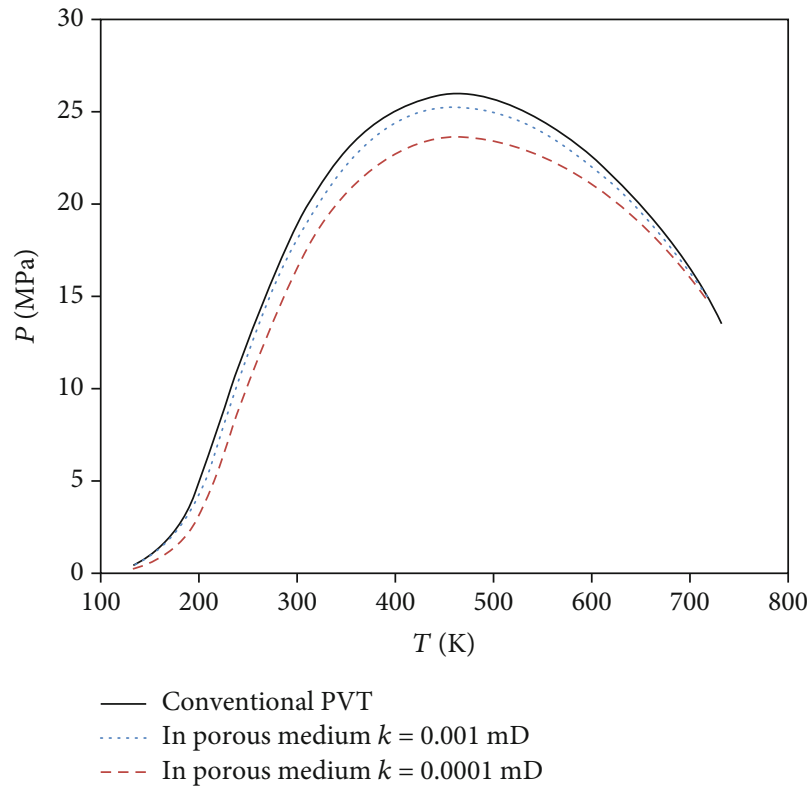

(a)

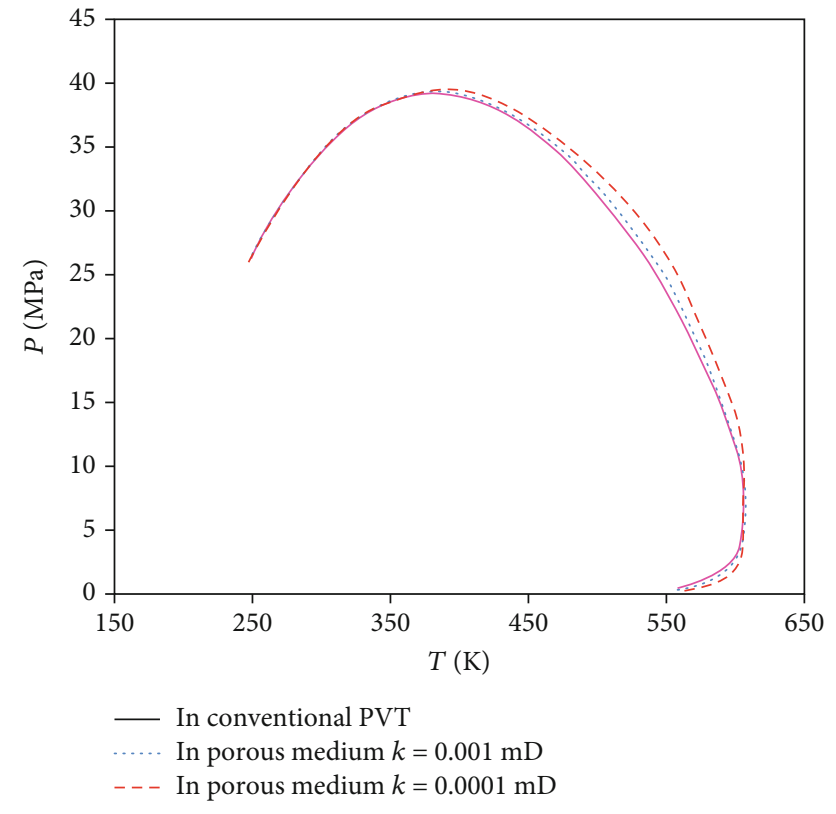

(b)

Figure 8: The effect of tight porous media on (a) bubble point and (b) dew point [47].

TABLE 1: Summary of the study on phase behavior in tight porous media.

\begin{tabular}{|c|c|c|}
\hline Objects & Reference & Results \\
\hline \multirow{2}{*}{ Wall effect } & Sandoval et al. [43] & It is necessary to consider the wall effect while simulating PVT \\
\hline & Lemus et al. [43] & experiment of shale oil. \\
\hline \multirow{6}{*}{ Bubble point } & Jiang [28] & $\begin{array}{l}\text { The pressure reduction of bubble point pressure in porous media } \\
\text { increases as the core permeability decreases. }\end{array}$ \\
\hline & Lemus et al. [43] & The bubble point pressure decreases because of the capillary pressure. \\
\hline & Nojabaei et al. [44] & The bubble point pressure decreases especially at the lower temperature. \\
\hline & Yang and Li [45] & $\begin{array}{l}\text { The phase envelope tends to shrink. The bubble point pressure of middle } \\
\text { Bakken oil decreases by } 17.32 \% \text { when the constraint effect is taken into account. }\end{array}$ \\
\hline & Pang et al. [47] & The bubble point decreases due to the capillary pressure. \\
\hline & Wu et al. [48] & The bubble point pressure decreases with the increase of pore size. \\
\hline \multirow[b]{2}{*}{ Dew point } & Pang et al. [47] & The dew point increases due to the capillary pressure. \\
\hline & Nojabaei et al. [44] & $\begin{array}{l}\text { There is either a decrease or increase for dew point pressure considering } \\
\text { the effect of small pores. }\end{array}$ \\
\hline Bubble point temperature & Sheng et al. [46] & The bubble point temperature increases as the pore diameter becomes smaller. \\
\hline \multirow[t]{2}{*}{ Minimum miscibility pressure } & $\begin{array}{l}\text { Wu et al. [48] } \\
\text { Zhu [49] }\end{array}$ & The MMP decreases with the increase of pore size. \\
\hline & Yu et al. [50] & The impurity gas increases the miscibility pressure. \\
\hline Critical temperature & Jiang [28] & The critical temperature has a linear negative correlation with the pore size. \\
\hline
\end{tabular}

used to analyze the microscopic flow of $\mathrm{CO}_{2}$ huff-n-puff in tight reservoirs.

4.1. NMR Experiments. NMR spectroscopy can be used to quantitatively analyze changes of fluid distribution, which is convenient for studying changes of oil saturation during $\mathrm{CO}_{2}$ huff-n-puff in tight oil reservoirs [56]. Ma et al. [23] ana- lyzed eight cycles of $\mathrm{CO}_{2}$ huff-n-puff by NMR spectroscopy and found that the crude oil in large pores was produced firstly, and then oil from small pores was produced gradually with the increase of $\mathrm{CO}_{2}$ huff-n-puff cycles (see Figure 10). Therefore, the proportion of crude oil produced from the large pores decreases, while the proportion of crude oil produced from the small pores increases gradually. Wang et al. 


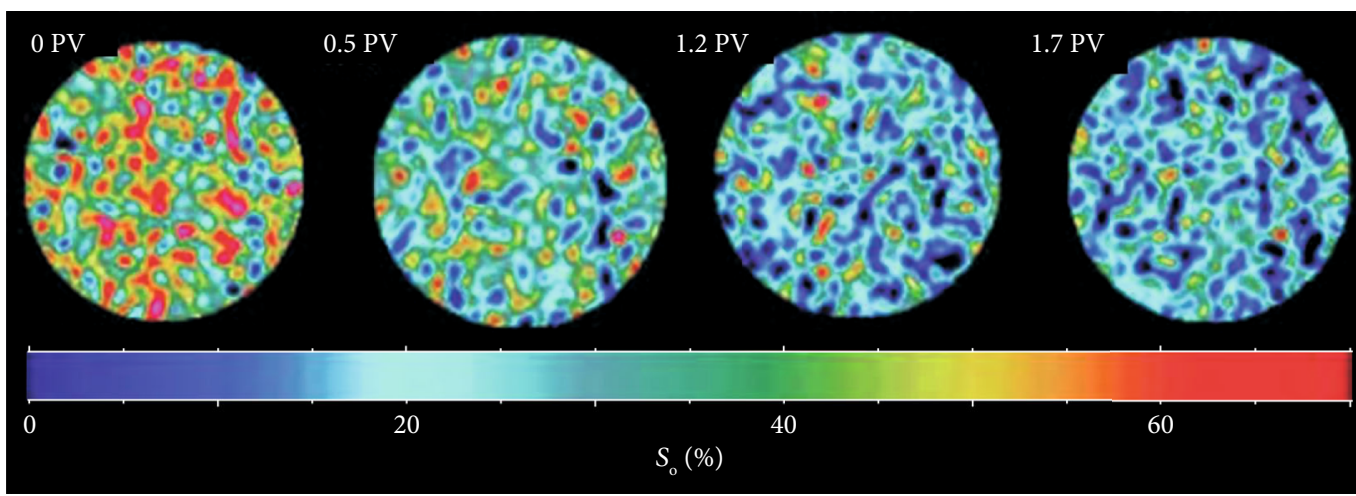

Figure 9: CT scanning images of residual oil at different $\mathrm{CO}_{2}$ injection volumes [51].

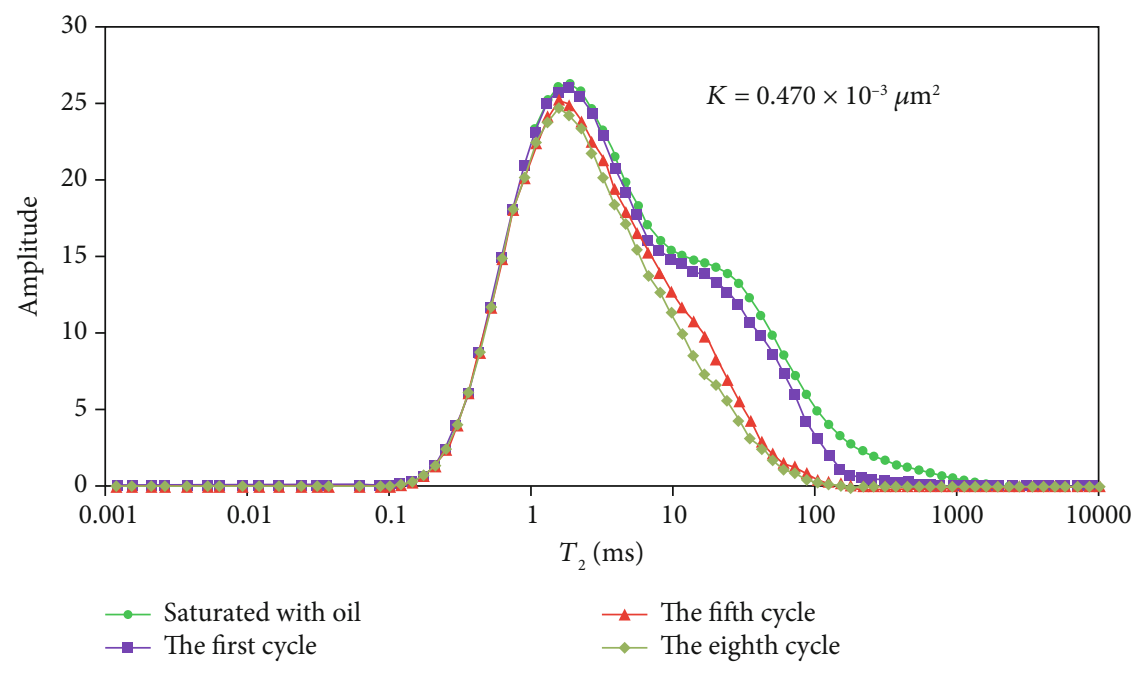

FIgURE 10: NMR spectroscopy of residual oil after different $\mathrm{CO}_{2}$ huff-n-puff cycles [23].

[57] pointed out that crude oil flowed out to the core surface due to the expansion of $\mathrm{CO}_{2}$ after $\mathrm{CO}_{2}$ injection, which caused the relaxation time of oil less than the original $645 \mathrm{~ms}$. In the first exposure experiment, the oil in each pore can be mobilized with the increase of the exposure time. More oil was produced from the macro pores $\left(29 \mathrm{~ms} \leq T_{2} \leq 645 \mathrm{~ms}\right)$ than that from the micro pores $\left(T_{2} \leq 29 \mathrm{~ms}\right.$ ) (see Figure 11).

Chen et al. [58] performed experiment using online NMR spectrometers and concluded that residual oil in tight cores is mainly distributed in pores with pore diameters below $0.1 \mu \mathrm{m}$ after $\mathrm{CO}_{2}$ displacement. Xiao et al. [59] analyzed immiscible flooding of $\mathrm{CO}_{2}$ in tight oil formation using physical simulation experiments and NMR. They pointed out that reducing asphaltene precipitation is essential to prevent core permeability reduction.

NMR experiments are applied to analyze the pore size distribution, residual oil distribution, and permeability changes. It can quickly quantify multiple indexes at the same time to better analyze the microscopic flow mechanism by NMR. However, the NMR experiment costs a lot compared with other methods. Besides, the core analyzed by NMR equipment is so small that it can only reflect microscopic flow in limited area in tight oil reservoirs. The main conclusions of microscopic flow in tight porous media by NMR are summarized in Table 2.

4.2. Molecular Simulation. Traditional methods are hard to analyze adsorption and flow characteristics of tight oil reservoirs due to the limitations of large proportion nanopores in tight oil reservoirs. With the development of computer science, molecular simulation has attracted wide attention to be recognized as a feasible method to investigate microscopic flow in tight oil reservoirs [60-62]. Guo [63] used the nonequilibrium molecular dynamics to simulate the flow of alkanes in quartz pores and dolomite pores. Results show that the velocity profiles of alkanes in quartz pores and dolomite pores are parabolic, and the velocity of alkane increases with the increase of driving force or pore width. $\mathrm{n}$-Pentane flows in quartz pores tends to slip, and the slip length increases with the increase of driving force, but decreases firstly and then tends to be stable with the increase of pore width (see Figure 12). However, no slip occurs in dolomite pores. The flow rate of n-pentane in two types of pores shows a nonlinear trend with the change of pressure gradient, in which convectional flow rules described by Darcy's law are not applicable. 


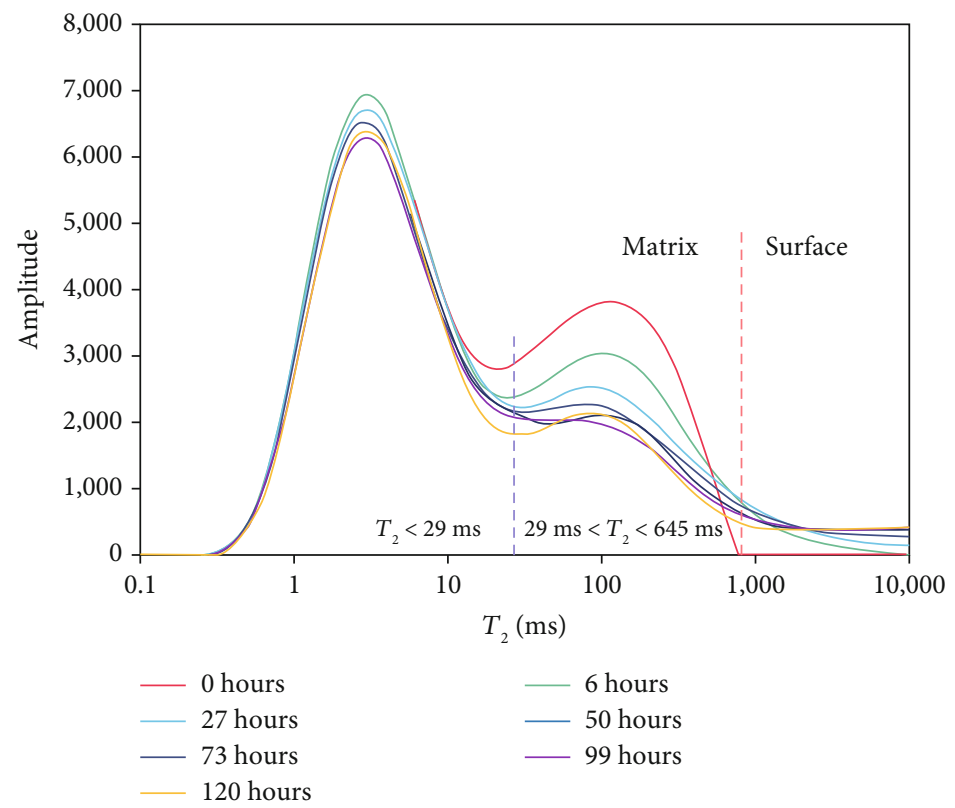

Figure 11: NMR $T_{2}$ spectra of the first exposure experiment [57].

TABLE 2: Summary of microscopic flow mechanisms by NMR.

\begin{tabular}{llr}
\hline Research contents & Reference & Main conclusions \\
\hline Oil flowing process & $\begin{array}{c}\text { The crude oil in the large pore is first produced, and then the crude } \\
\text { oil in the small pore is gradually produced under the action } \\
\text { of concentration difference and molecular diffusion. }\end{array}$ \\
$\begin{array}{l}\text { Wesidual oil distribution } \\
\text { Permeability }\end{array}$ & $\begin{array}{c}\text { The crude oil flows out to the core surface due to the expansion of } \mathrm{CO}_{2} . \\
\text { The oil in each pore can be mobilized with the increase of the } \\
\text { exposure time in the first exposure experiment. }\end{array}$ \\
\hline Xiao et al. [59] & $\begin{array}{c}\text { After } \mathrm{CO}_{2} \text { displacement, residual oil was mainly distributed in pores } \\
\text { with pore diameter below } 0.1 \mu \mathrm{m} .\end{array}$ \\
\hline
\end{tabular}

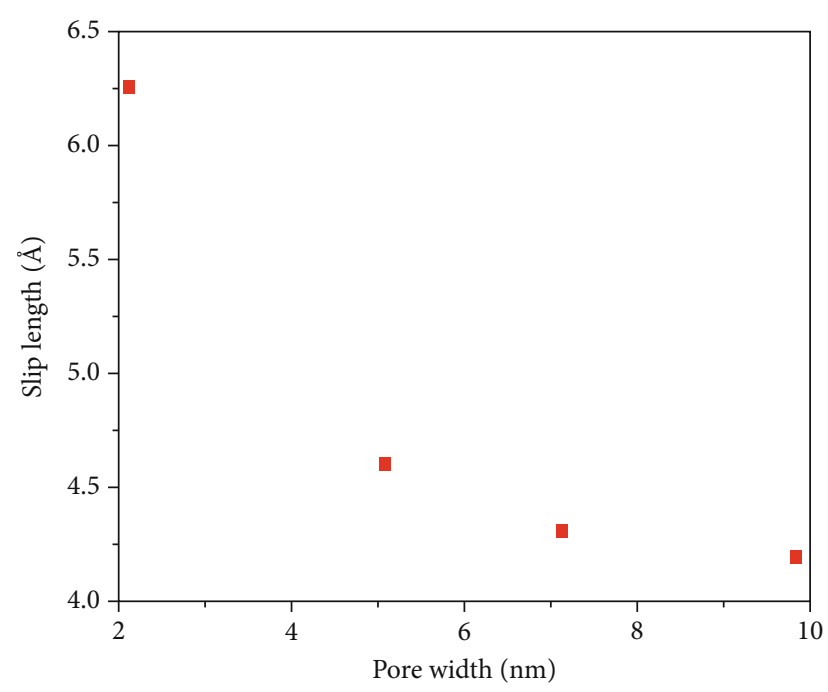

FIGURE 12: The relation between slip length and pore width of $\mathrm{n}$ pentane flowing in quartz pore [63].
Slip phenomenon occurs when gas flows through porous media, especially in unconventional reservoirs [64]. Duan et al. [65] proposed an apparent permeability model to describe the gas flow in tight pores considering the boundary layer. The result shows that the velocity profile is plungerlike, and the velocity of gas molecules at the wall is consistent with that of free phase gas molecules (see Figure 13). This indicates that the slippage of gas molecules is significant at the wall. With the increase of pressure, the slippage phenomenon disappears gradually.

Zhu et al. [66] studied the $\mathrm{CO}_{2}$ huff-n-puff with Niobrara samples saturated with $\mathrm{C}_{10}$ and $\mathrm{C}_{17}$ by molecular dynamics simulation and found that $\mathrm{CO}_{2}$ molecules could replace $\mathrm{C}_{10}$ and $\mathrm{C}_{17}$ on the surface of calcite, which results in desorption and flow of hydrocarbon molecules. To analyze $\mathrm{CO}_{2}$ huff-npuff in organic shale, Ali et al. [67] created the kerogen molecular structure and simulated $\mathrm{CO}_{2}$ huff-n-puff in shale saturated with dodecane by molecular dynamics. The results indicate that there is an optimal soaking time after which the recovery factor is not affected by soaking time anymore. 


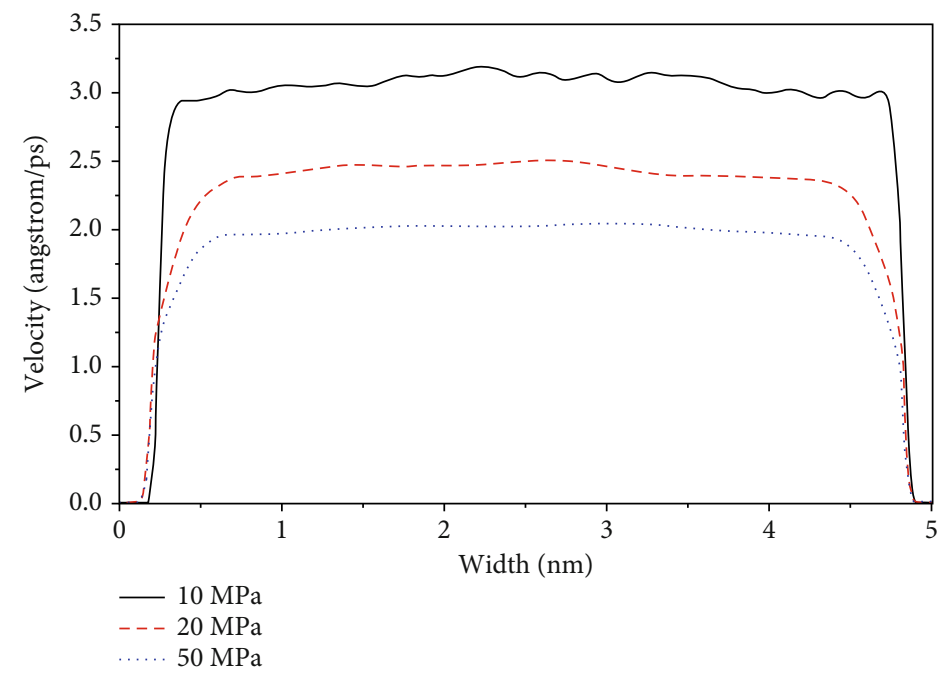

FIGURE 13: Simulation results of velocity profiles for $5 \mathrm{~nm}$ slit under different pressures [65].

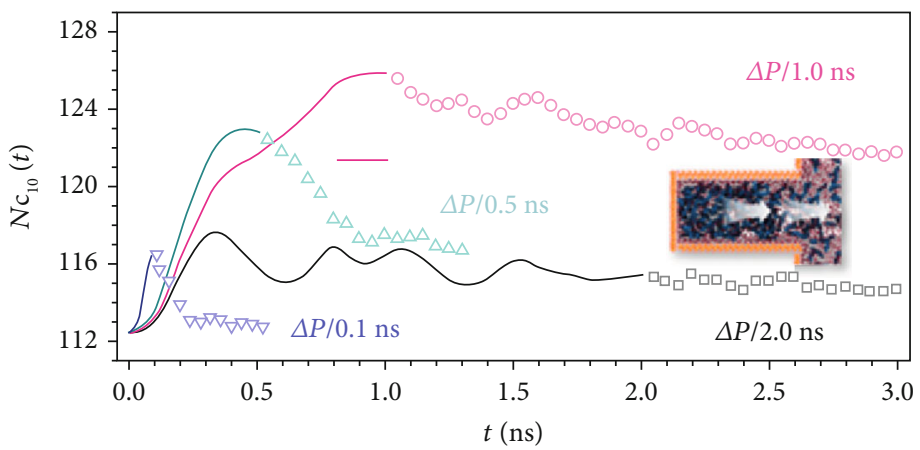

Figure 14: Extraction results of $C_{10}$ molecules with different depressurization rate [68].

Additionally, $\mathrm{CO}_{2}$ is more easily adsorbed than dodecane so that dodecane is replaced by $\mathrm{CO}_{2}$. Fang et al. [68] simulated the process of $\mathrm{CO}_{2}$ extracting hydrocarbon with reservoir depressurization by molecular dynamics. The calculation results show that the extraction amount of the alkane is different with depressurization rate changes. An appropriate depressurization rate can keep extraction at a high value (see Figure 14).

Molecular simulation can be used to analyze the flow velocity, flow rate, slip, adsorption, and extraction during $\mathrm{CO}_{2}$ huff-n-puff in tight oil reservoirs. But only small-scale molecular simulation is available due to the complicated and large-scale calculation at present. The composition of porous media and fluid simulated by molecular simulation is relatively simple compared with the real situation. Besides, pore shapes are diverse and the surface of pore is rough, which needs to be taken into account for molecular simulation [69]. Hence, the molecular simulation needs to be improved to better model microscopic flow and achieve more accurate results. The results of microscopic flow in tight porous media by molecular simulation are summarized in Table 3.

4.3. Other Methods. Other methods are also used to study the microscopic flow besides NMR and molecular simulation.
Zhou et al. [70] pointed out that sand filling model shows poor reference to the application in tight oil reservoirs so that the outcrop plate model was applied to discuss the influence of injection pressure on $\mathrm{CO}_{2}$ huff-n-puff. When $\mathrm{CO}_{2}$ is injected with a pressure lower than miscibility pressure, $\mathrm{CO}_{2}$ enters the matrix in a free state, causing $\mathrm{CO}_{2}$ fingering in the porous media. And $\mathrm{CO}_{2}$ is dissolved in the crude oil after soaking at a pressure higher than the miscibility pressure. Some crude oil traps the free $\mathrm{CO}_{2}$ inside the matrix. In the production stage, the free $\mathrm{CO}_{2}$ forms gas driving directly with pressure decreasing, which is beneficial to improve the EOR efficiency. Nguyen et al. [71] conducted direct visualization experiments with a microfluidic system. Results show that the efficiency of huff-n-puff depends on the solubility and miscibility of injected gas in crude oil. $\mathrm{CO}_{2}$ is more soluble in crude oil than $\mathrm{N}_{2}$. During the production stage, $\mathrm{CO}_{2}$ can form more bubbles in the fracture network, which gradually expand with the local mass transferring between gas and liquid. With pressure reduction, bubbles displace the crude oil (see Figure 15). Alfarge et al. [72] confirmed that molecular diffusion is the main factor to control $\mathrm{CO}_{2}$ EOR in shale through comprehensive experimental investigation, field test data, and numerical simulation. Through core experiments, it is speculated that the exposure time and contact area between the injected $\mathrm{CO}_{2}$ 
TABLE 3: Summary of microscopic flow mechanisms by molecular simulation.

\begin{tabular}{|c|c|c|}
\hline Objects & Reference & Results \\
\hline \multirow[t]{2}{*}{ Flow velocity } & Guo [63] & $\begin{array}{l}\text { In quartz pores and dolomite pores, the flow velocity profile } \\
\text { of alkane is parabolic, and the flow velocity of alkane increases } \\
\text { with the increase of driving force or pore width. }\end{array}$ \\
\hline & Duan et al. [65] & $\begin{array}{l}\text { The velocity profile is plunger-like, and the velocity of gas } \\
\text { molecules at the wall is consistent with that of free gas molecules. }\end{array}$ \\
\hline \multirow[t]{2}{*}{ Slip } & Guo [63] & $\begin{array}{l}\text { The slip length of } \mathrm{n} \text {-pentane flowing in quartz pores increases } \\
\text { with the increase of driving force, and decreases firstly and then tends to } \\
\text { be stable as the pore width increases. }\end{array}$ \\
\hline & Duan et al. [65] & The slippage phenomenon disappears gradually as the pressure increases. \\
\hline Flow rate & Guo [63] & $\begin{array}{l}\text { The flow rate of n-pentane in pores shows a nonlinear trend } \\
\text { with the change of pressure gradient. }\end{array}$ \\
\hline \multirow{2}{*}{ Desorption } & Zhu et al. [66] & $\mathrm{CO}_{2}$ could replace $\mathrm{C}_{10}$ and $\mathrm{C}_{17}$ from the surface of calcite. \\
\hline & Ali et al. [67] & Dodecane could be replaced by $\mathrm{CO}_{2}$ from the pore wall. \\
\hline Extraction & Fang et al. [68] & An appropriate depressurization rate can keep extraction at a high status. \\
\hline
\end{tabular}

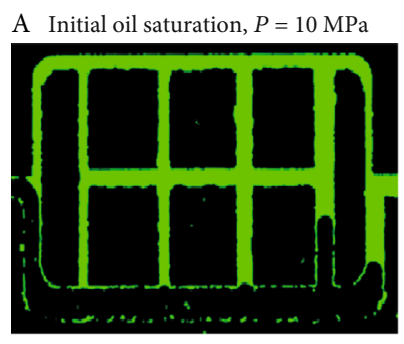

B Oil saturation $=93 \%, P=7 \mathrm{MPa}$

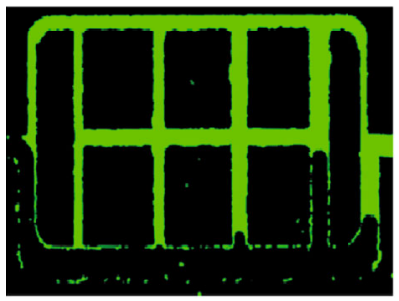

C Oil saturation $=92 \%, P=3.5 \mathrm{MPa}$

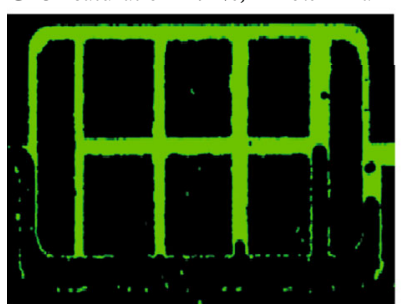

(a) $\mathrm{N}_{2}$ huff-n-puff

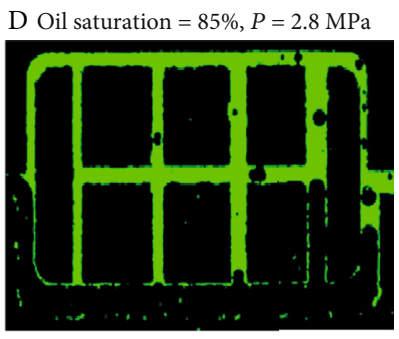

E Oil saturation $=80 \%, P=0.5 \mathrm{MPa}$

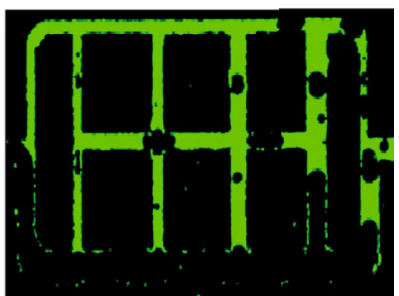

F Oil saturation $=60 \%, P=0.2 \mathrm{MPa}$

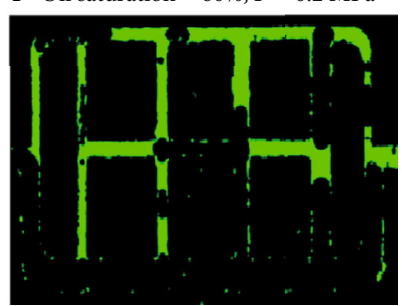

FIGURE 15: Images in visual fracture networks during depressurization [71].

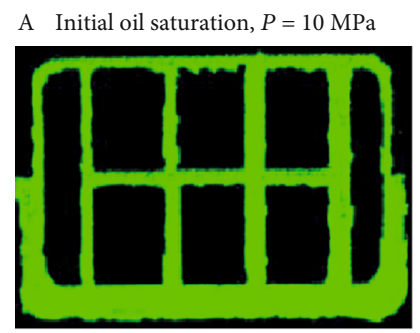

B Oil saturation $=82 \%, P=7 \mathrm{MPa}$

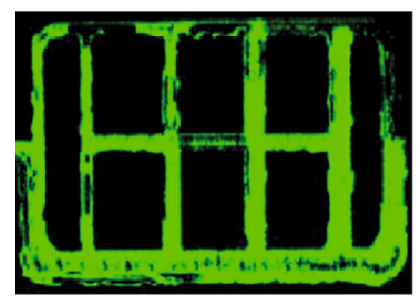

C Oil saturation $=40 \%, P=5 \mathrm{MPa}$

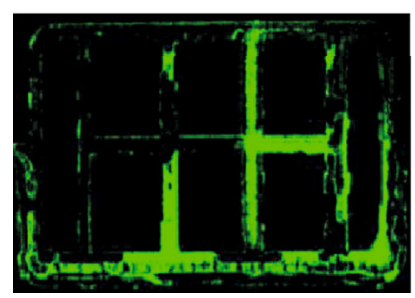

(b) $\mathrm{CO}_{2}$ huff-n-puff
D Oil saturation $=15 \%, P=2.5 \mathrm{MPa}$

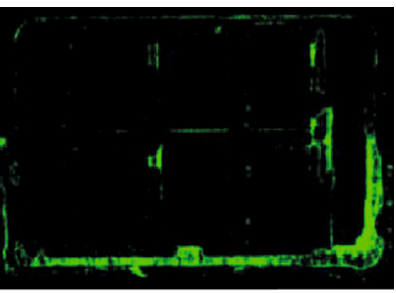

E Oil saturation $=10 \%, P=2 \mathrm{MPa}$

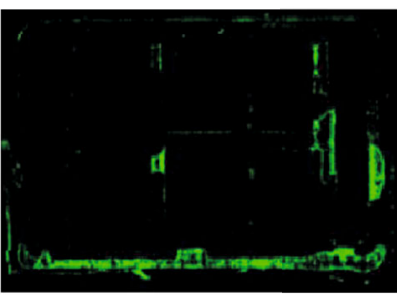

F $\quad$ Oil saturation $=5 \%, P=1 \mathrm{MPa}$

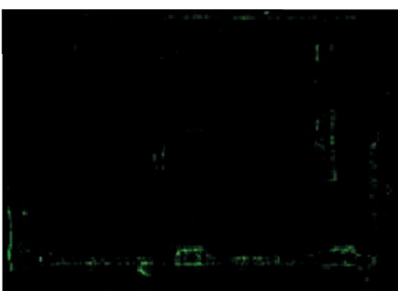

and the target formation need to be significantly increased to achieve better EOR performance during the $\mathrm{CO}_{2}$ huff-n-puff. Li et al. [73] studied the penetration depth of $\mathrm{CO}_{2}$ huff-n-puff in tight oil reservoirs based on core experiments and numerical simulation. The results showed that the penetration depth of $\mathrm{CO}_{2}$ in the first cycle was $105.6 \mathrm{ft}$ and the penetration volume was approximately $36 \%$ of the reservoir volume in reservoirs where the hydraulic fracture spacing was $600 \mathrm{ft}$.
Natural fracture spacing shows the greatest impact on the penetration depth.

Most of the pre-Darcy flow models may cause errors due to the improvement of crude oil properties with $\mathrm{CO}_{2}$ injection in simulation of the nonlinear flow degree. Based on the high-precision experimental data of representative cores in Fuyu reservoir, Wang et al. [74] proposed a new preDarcy model to characterize the influence of $\mathrm{CO}_{2}$ huff-n- 


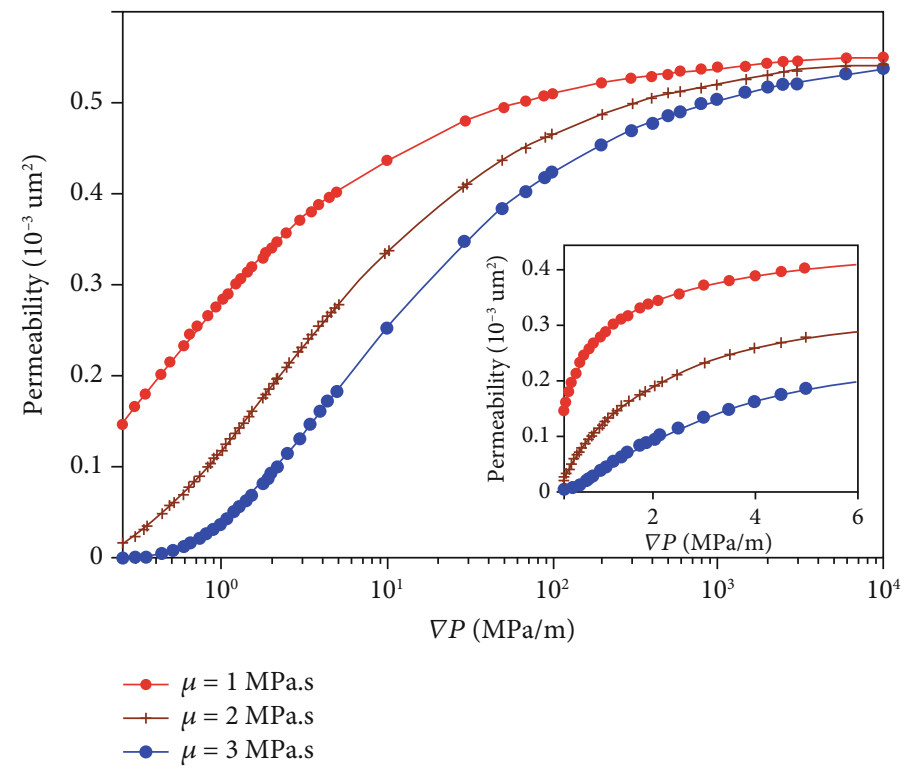

FiguRE 16: The relationship between absolute permeability and displacement pressure gradient under different fluid viscosities [75].

TABLe 4: Summary of microscopic flow mechanisms by other methods.

\begin{tabular}{|c|c|c|}
\hline Methods & Reference & Main conclusions \\
\hline \multicolumn{3}{|l|}{ Experiments } \\
\hline Outcrop plate model experiment & Zhou et al. [70] & $\begin{array}{l}\text { To inject } \mathrm{CO}_{2} \text { at pressure lower than miscible pressure, which is } \\
\text { conducive to } \mathrm{CO}_{2} \text { fingering into the reservoir and driving out more } \\
\text { crude oil when the well is opened. }\end{array}$ \\
\hline $\begin{array}{l}\text { Direct visualization experiments with a } \\
\text { microfluidic system }\end{array}$ & Nguyen et al. [71] & $\begin{array}{l}\text { The solubility of } \mathrm{CO}_{2} \text { is bigger than that of } \mathrm{N}_{2} \text { so that } \mathrm{CO}_{2} \text { forms } \\
\text { more bubbles within the fracture. Bubbles gradually expand } \\
\text { with the local mass transferring between gas and liquid and } \\
\text { pressure reduction, and then displace the crude oil. }\end{array}$ \\
\hline Core experiment & Alfarge et al. [72] & $\begin{array}{l}\text { Increasing the exposure time and contact area between the injected } \\
\mathrm{CO}_{2} \text { and the target formation can achieve better performance } \\
\text { of } \mathrm{CO}_{2} \text { huff-n-puff. }\end{array}$ \\
\hline Core experiment and numerical simulation & Li et al. [73] & $\begin{array}{l}\text { Natural fracture spacing shows the greatest impact on the } \\
\qquad \mathrm{CO}_{2} \text { penetration depth. }\end{array}$ \\
\hline \multicolumn{3}{|l|}{ Theory } \\
\hline Pre-Darcy model & Wang et al. [74] & $\begin{array}{l}\text { The pre-Darcy flow models can reduce errors caused by } \\
\text { the improvement of crude oil properties while simulating } \\
\text { the nonlinear flow degree. }\end{array}$ \\
\hline Mathematical model & Chen et al. [75] & $\begin{array}{c}\text { Due to the boundary layer effect, the absolute permeability } \\
\text { is no longer a fixed value. }\end{array}$ \\
\hline
\end{tabular}

puff on the description of nonlinear flow degree. The simulation results show that the proposed pre-Darcy flow model can describe the reduction of the nonlinear degree well when the properties of crude oil are improved. Chen et al. [75] established a mathematical model considering boundary layer effect based on the three-dimensional random network model. The factors affecting pore scale flows in tight formation are analyzed. The results showed that the absolute permeability is no longer a fixed value due to the boundary layer effect, but it increases as the pressure gradient increases. When the displacement pressure gradient is large enough, the permeability reaches a stable value, which is independent of the fluid viscosity (see Figure 16). Under the same pressure gradient, the connectivity becomes greater, and absolute permeability and velocity increase as the average coordination number of the pore increases. At the same pressure gradient, the boundary layer becomes thicker as the fluid viscosity increases. Also, the effective flow space becomes smaller, and the permeability and velocity decrease.

The above experimental and theoretical researches are summarized in Table 4. Experimental researches are visualized while theoretical researches are more precise and intrinsic, which provides new ways to study the microscopic flow mechanism of $\mathrm{CO}_{2}$ huff-n-puff in tight oil reservoirs.

In this section, the microscopic flow mechanism of $\mathrm{CO}_{2}$ huff-n-puff in tight oil reservoirs is discussed. Various 
methods are investigated and classified. NMR can quantify residual oil distribution and permeability quickly, while molecular simulation can be used to analyze the flow velocity, flow rate, and slip in tight oil reservoirs clearly. Other methods provide new visible ways and models to analyze the microscopic flow mechanism of $\mathrm{CO}_{2}$ huff-n-puff in tight oil reservoirs.

The above researches are of great significance to better understand the microscopic flow mechanism of $\mathrm{CO}_{2}$ huffn-puff in tight oil reservoirs. In the near future, the improved molecular simulation is a considerable method to study the microscopic flow mechanism because the molecular-level flow mechanism can be discussed by molecular simulation while traditional methods cannot do it. The microscopic flow model in micropore network based on digital core is worth to be established, and it is important that phase behavior be taken account into the microscopic flow model of $\mathrm{CO}_{2}$ huff-n-puff in tight porous media.

\section{Conclusions}

Understanding of phase behavior in tight porous media and microscopic flow mechanism is important for optimizing $\mathrm{CO}_{2}$ huff-n-puff in tight oil reservoirs.

(1) The effect of $\mathrm{CO}_{2}$ huff-n-puff is mainly reflected in the injection stage (pressure supplement), the soaking stage (the dissolution and diffusion), and the production stage (the dissolved gas driving), during which the viscosity of crude oil has been decreased and the oil flows much easier. Soaking time and $\mathrm{CO}_{2}$ diffusivity are two important factors for enhancing oil recovery factor through the numerical simulations of $\mathrm{CO}_{2}$ huff-n-puff. The difference of phase behavior and microscopic flow mechanism in tight porous media from that in conventional reservoirs cannot be ignored in the numerical simulations

(2) The effect of tight porous media on the phase behavior of fluid cannot be ignored since the capillary pressure in tight porous media reduces the bubble point pressure, increases the miscibility pressure and critical temperature, and shrinks the phase envelope. The difference between the condensate pressure in the tight porous media and that in a PVT cylinder needs to be discussed, which is significant for the development of gas-condensate reservoirs. Additionally, nonequilibrium phase behavior and the influence of capillary pressure on phase behavior need to be further investigated to make the results more consistent with the real situation

(3) The microscopic flow of fluid in tight oil reservoirs is different from that in conventional reservoirs because molecular diffusion, gas-liquid interaction, and fluidrock interaction are especially predominant in tight porous media. NMR and molecular simulation are significant methods to understand the microscopic flow in tight oil reservoirs, while NMR can quickly quantify several indexes at the same time and molec- ular simulation can be used to analyze the molecularlevel movement of gas and oil clearly. In the future, the improved molecular simulation is still a feasible method to describe and investigate the microscopic flow mechanism of $\mathrm{CO}_{2}$ huff-n-puff in tight oil reservoirs. The microscopic flow model in micropore network based on digital core is worth to be established, and the phase behavior needs to be taken into account the microscopic flow model

\section{Conflicts of Interest}

The authors declare that they have no conflict of interest.

\section{Acknowledgments}

This work was supported by the National Natural Science Foundation of China (51974268), the Key Project of Sichuan Science and Technology Department (2019YJ0423), and the Major Special Projects of PetroChina (2014E-3602).

\section{References}

[1] B. Jia, J. S. Tsau, and R. Barati, "Role of molecular diffusion in heterogeneous shale reservoirs during $\mathrm{CO}_{2}$ huff-n-puff," in Proceeding of SPE Europec featured at 79th EAGE Conference and Exhibition, Paris, France, 2017.

[2] B. Madden and S. Vossoughi, "US shale gas and tight oil boom - the opportunities and risks for America," in Proceeding of SPE Asia Pacific Oil and Gas Conference and Exhibition, Jakarta, Indonesia, October 2013.

[3] D. Du, W. Pu, J. Yang, and L. Rui, "Experimental study on EOR by $\mathrm{CO}_{2}$ huff-n-puff and $\mathrm{CO}_{2}$ flooding in tight conglomerate reservoirs with pore scale," Chemical Engineering Research and Design, vol. 156, pp. 425-432, 2020.

[4] J. Guo, R. Xie, and L. Xiao, "Pore-fluid characterizations and microscopic mechanisms of sedimentary rocks with threedimensional NMR: tight sandstone as an example," Journal of Natural Gas Science and Engineering, vol. 80, article 103392, 2020.

[5] C. R. Clarkson and P. K. Pedersen, "Tight oil production analysis: adaptation of existing rate-transient analysis techniques," in Proceeding of Canadian Unconventional Resources and International Petroleum Conference, SPE Paper SPE-137352MS, Calgary, Canada, October 2010.

[6] X. Liu, F. An, Q. Chen, and J. Qin, "Analyses of the EOR techniques for tight oil reservoir: taking Bakken-Formation as an example," Petroleum Geology and Oilfield Development in Daqing, vol. 35, no. 6, pp. 164-169, 2016.

[7] B. T. Hoffman and J. M. Rutledge, "Mechanisms for huff-npuff cyclic gas injection into unconventional reservoirs," in Proceeding of SPE Oklahoma City Oil and Gas Symposium, SPE Paper SPE-195223-MS, Oklahoma City, OK, USA, April 2019.

[8] B. Wei, M. Zhong, K. Gao et al., "Oil recovery and compositional change of $\mathrm{CO}_{2}$ huff-n-puff and continuous injection modes in a variety of dual-permeability tight matrix-fracture models," Fuel, vol. 276, article 117939, 2020.

[9] B. T. Hoffman and J. G. Evans, "Improved oil recovery IOR pilot projects in Bakken formation," in Proceeding of Low Perm 
Symposium, SPE Paper SPE-1 80270-MS, Denver, CO, USA, May 2016.

[10] Y. He, S. Cheng, Z. Sun, Z. Chai, and Z. Rui, "Improving oil recovery through fracture injection and production of multiple fractured horizontal wells," Journal of Energy Resources Technology, vol. 142, no. 5, pp. 1-19, 2020.

[11] D. Alarge, M. Wei, and B. Bai, "IOR methods in unconventional reservoirs of North America: comprehensive review," in Proceeding of SPE Western Regional Meeting, SPE Paper SPE-185640-MS, Bakersfield, CA, USA, April 2017.

[12] H. Madhoo, A. Acevedo, M. Koley, I. Bryant, and R. Laver, "An optimal approach to shale gas and oil exploration beyond North America," in Proceeding of SPE/EAGE European Unconventional Resources Conference and Exhibition, Vienna, Austria, February 2014.

[13] T. Phi and D. Schechter, " $\mathrm{CO}_{2}$ EOR simulation in unconventional liquid reservoirs: an Eagle Ford case study," in Proceeding of SPE Unconventional Resources Conference, Calgary, Alberta, Canada, February 2017.

[14] P. Pankaj, H. Mukisa, I. Solovyeva, and H. Xue, "Enhanced oil recovery in Eagle Ford: opportunities using huff-n-puff technique in unconventional reservoirs," in Proceeding of SPE Liquids-Rich Basins Conference - North America, Midland, TX, USA, September 2018.

[15] S. Mamoudou, F. Perez, A. Tinni et al., "Evaluation of huff-npuff in shale using experiments and molecular simulations," in Proceeding of SPE/AAPG/SEG Unconventional Resources Technology Conference, 2020.

[16] Y. He, J. Qin, S. Cheng, and J. Chen, "Estimation of fracture production and water breakthrough locations of multi-stage fractured horizontal wells combining pressure-transient analysis and electrical resistance tomography," Journal of Petroleum Science and Engineering, vol. 194, article 107479, 2020.

[17] S. A. Cox, D. Cook, K. Dunek, G. R. Daniels, C. J. Jump, and R. D. Barree, "Unconventional resource play evaluation: a look at the Bakken shale play of North Dakota," in Proceeding of SPE Unconventional Reservoirs Conference, SPE Paper SPE114171-MS, Keystone, CO, USA, February 2008.

[18] P. Zuloaga-Molero, W. Yu, Y. Xu, K. Sepehrnoori, and B. Li, "Simulation study of $\mathrm{CO}_{2}$-EOR in tight oil reservoirs with complex fracture geometries," Scientific Reports, vol. 6, no. 1, pp. 33445-33455, 2016.

[19] J. Moore, D. Crandall, and S. Workan, "A new methodology to evaluate huff and puff effectiveness at in-situ conditions," in Proceeding of SPE/AAPG/SEG Unconventional Resources Technology Conference, 2020.

[20] Y. Tang, S. Hu, Y. He et al., "Experiment on $\mathrm{CO}_{2}$-brine-rock interaction during $\mathrm{CO}_{2}$ injection and storage in gas reservoirs with aquifer," Chemical Engineering Journal, 2021.

[21] C. Song and D. Yang, "Experimental and numerical evaluation of $\mathrm{CO}_{2}$ huff-n-puff processes in Bakken formation," Fuel, vol. 190, pp. 145-162, 2017.

[22] Y. Wang, J. Hou, Z. Song, D. Yuan, J. Zhang, and T. Zhao, “A case study on simulation of in-situ $\mathrm{CO}_{2}$ Huff-'n'-Puff process," SPE Reservoir Evaluation \& Engineering, vol. 21, no. 1, pp. 109-121, 2018.

[23] Q. Ma, S. Yang, H. Chen et al., "Effect and influencing factors of $\mathrm{CO}_{2}$ huff and puff in a tight oil reservoir-taking the Lucaogou formation in the Xinjiang Jimsar sag as an example," Petroleum Science Bulletin, vol. 3, no. 4, pp. 434-445, 2018.
[24] Y. Tang, Z. Su, J. He, and F. Yang, "Numerical simulation and optimization of enhanced oil recovery by the in situ generated CO2Huff-n-Puff process with compound surfactant," Journal of Chemistry, vol. 2016, Article ID 6731848, 13 pages, 2016.

[25] C. Chen, M. T. Balhoff, and K. K. Mohanty, "Effect of reservoir heterogeneity on primary recovery and $\mathrm{CO}_{2}$ huff ' $\mathrm{n}$ ' puff recovery in shale-oil reservoirs," SPE Reservoir Evaluation \& Engineering, vol. 17, no. 3, pp. 404-413, 2014.

[26] Y. Wang, J. Hou, and Y. Tang, "In-situ $\mathrm{CO}_{2}$ generation huff-npuff for enhanced oil recovery: laboratory experiments and numerical simulations," Journal of Petroleum Science and Engineering, vol. 145, pp. 183-193, 2016.

[27] A. Ellafi and H. Jabbari, "Understanding the mechanisms of huffn-puff, CO2-EOR in liquid-rich shale plays: Bakken case study," in Proceeding of SPE Canada Unconventional Resources Conference, SPE Paper SPE-200001-MS, September-October 2020.

[28] Y. Jiang, "Experiment and characterization on phase behavior of $\mathrm{CO}_{2}$ and crude oil in porous media," Reservoir Evaluation and Development, vol. 10, no. 3, pp. 23-27, 2020.

[29] W. Yu, H. Lashgari, and K. Sepehrnoori, "Simulation study of $\mathrm{CO}_{2}$ huff-n-puff process in Bakken tight oil reservoirs," in Proceeding of SPE Western North American and Rocky Mountain Joint Meeting, SPE Paper SPE-169575-MS, Denver, CO, USA, April 2014.

[30] L. Li, Z. Jing, X. Zhao et al., "Understanding of $\mathrm{CO}_{2}$ huff and puff effect of Chang 7 tight oil in Y oilfield," Petrochemical Industry Application, vol. 37, no. 1, pp. 46-48+52, 2018.

[31] S. B. Hawthorne, C. D. Gorecki, J. A. Sorensen, E. N. Steadman, J. A. Harju, and S. Melzer, "Hydrocarbon mobilization mechanisms from upper, middle, and lower Bakken reservoir rocks exposed to $\mathrm{CO}_{2}$," in Proceeding of SPE Unconventional Resources Conference, SPE paper SPE-167200-MS, Calgary, Alberta, Canada, November 2013.

[32] G. Hou, "Practice and understanding of the $\mathrm{CO}_{2}$ huff-puff for the volume fractured horizontal well in tight oil reservoirs," Petroleum Geology and Oilfield Development in Daqing, vol. 37, no. 3, pp. 163-167, 2018.

[33] A. Bera and T. Babadagli, "Relative permeability of foamy oil for different types of dissolved gases," SPE Reservoir Evaluation \& Engineering, vol. 19, no. 4, pp. 604-619, 2016.

[34] Y. Jia, L. Huang, and L. Sun, “The mechanism and simulation research of 'foamy oil' during CO2 flooding," in Proceeding of Carbon Management Technology Conference, Houston, TX, USA, July 2017.

[35] C. Or, K. Sasaki, Y. Sugai, M. Makano, and M. Imai, "Swelling and viscosity reduction of heavy oil by $\mathrm{CO}_{2}$-Gas foaming in immiscible condition," SPE Reservoir Evaluation \& Engineering, vol. 19, no. 2, pp. 294-304, 2016.

[36] P. Zuloaga, W. Yu, J. Miao, and K. Sepehrnoori, "Performance evaluation of $\mathrm{CO}_{2}$ huff-n-puff and continuous $\mathrm{CO}_{2}$ injection in tight oil reservoirs," Energy, vol. 134, pp. 181-192, 2017.

[37] R. Sun, W. Yu, F. Xu, H. Pu, and J. Miao, "Compositional simulation of $\mathrm{CO}_{2}$ huff-n-puff process in middle Bakken tight oil reservoirs with hydraulic fractures," Fuel, vol. 236, pp. 14461457, 2019.

[38] C. Wang, Experimental study on $\mathrm{CO}_{2}$ injection in tight reservoir, Master's Thesis, Southwest Petroleum University, 2016.

[39] Z. Yang, X. Liu, Z. Zhang, T. Zhou, and S. Zhao, "Physical simulation of staged-fracturing horizontal wells using $\mathrm{CO}_{2}$ huff and puff in tight oil reservoirs," Acta Petrolei Sinica, vol. 36, no. 6, pp. 724-729, 2015. 
[40] G. Liu, "Optimization of injection and production parameters of $\mathrm{CO}_{2}$ huff and puff by horizontal wells with volume fracturing in tight oil," Petroleum Geology and Engineering, vol. 34, no. 2, pp. 90-93, 2020.

[41] J. Ma, X. Wang, R. Gao et al., "Enhanced light oil recovery from tight formations through $\mathrm{CO}_{2}$ huff 'n' puff processes," Fuel, vol. 154, pp. 35-44, 2015.

[42] Y. Tang, S. Hu, Y. Wang et al., "Phase behaviors of $\mathrm{CO}_{2}$ in the whole process of injection-fracturing-flowback: a case study of well SH52 in a tight sandstone gas reservoir of the Shenmu Gas Field, Ordos Basin," Natural Gas Industry, vol. 39, no. 9, pp. 58-64, 2019.

[43] D. R. S. Lemus, W. Yan, and E. H. Stenby, "Phase equilibrium in shale including porous media effects," in Proceeding of International Petroleum Exhibition and Conference, SPE Paper SPE-197278-MS, Abu Dhabi, UAE, November 2019.

[44] B. Nojabaei, R. T. Johns, and L. Chu, "Effect of capillary pressure on phase behavior in tight rocks and shales," SPE Reservoir Evaluation \& Engineering, vol. 16, no. 3, pp. 281-289, 2013.

[45] G. Yang and X. Li, "Improved equation of state model for gas huff-n-puff EOR processes in unconventional reservoirs," in Proceeding of SPE/AAPG/SEG Unconventional Resources Technology Conference, URTEC-2020-3179-MS, 2020.

[46] L. Sheng, J. L. Lutkenhaus, and H. Nasrabadi, "Experimental study of confinement effect on hydrocarbon phase behavior in nano-scale porous media using differential scanning calorimetry," in Proceeding of SPE Annual Technical Conference and Exhibition, SPE Paper SPE-175095-MS, Houston, TX, USA, September 2015.

[47] J. Pang, J. Zuo, D. Zhang, and L. Du, "Effect of porous media on saturation pressures of shale gas and shale oil," in Proceeding of SPE Canadian Unconventional Resources Conference, SPE Paper SPE-161143-MS, Calgary, Canada, 2012.

[48] S. Wu, Z. Li, H. K. Sarma, C. Zhang, and G. Lv, "Impact of fluid property shift and capillarity on the recovery mechanisms of CO2injection in tight oil reservoirs," Greenhouse Gases: Science \& Technology, vol. 9, no. 5, pp. 965-978, 2019.

[49] N. Zhu, Research on phase behavior change and seepage characteristics of $\mathrm{CO}_{2}$ and oil in porous media, $\mathrm{PhD}$ Degree Thesis, Dalian University of Technology, 2013.

[50] H. Yu, X. Lu, W. Fu et al., "Determination of minimum near miscible pressure region during $\mathrm{CO}_{2}$ and associated gas injection for tight oil reservoir in Ordos Basin China," Fuel, vol. 263, article 116737, 2020.

[51] N. Li, X. Tan, X. Tian, H. Wu, and X. Li, "Study on the phase behavior and displacement characteristics of $\mathrm{CO}_{2}$ flooding in porous media," Jounal of Chengdu University of Technology (Science \& Technology Edition), vol. 45, no. 4, pp. 501-504, 2018.

[52] C. J. Werth, C. Zhang, M. L. Brusseaau, M. Oostrom, and T. Baumann, "A review of non-invasive imaging methods and applications in contaminant hydrogeology research," Journal of Contaminant Hydrogeology, vol. 113, no. 1-4, pp. 1-24, 2010.

[53] Z. Jin and A. Firoozabadi, "Phase behavior and flow in shale nanopores from molecular simulations," in Proceeding of SPE Annual Technical Conference and Exhibition, Houston, TX, USA, September 2015.

[54] T. Wu and A. Firoozabadi, "Methane flow in shale nanopores with kerogen microstructure by molecular simulations," in
Proceeding of SPE Annual Technical Conference and Exhibition, Dallas, TX, USA, September 2018.

[55] Y. Tang, C. Hou, Y. He et al., "Review on pore structure characterization and microscopic flow mechanism of CO2 flooding in porous media," Energy Technology, 2020.

[56] D. Asthagiri, P. M. Singer, A. V. Parambathu, Z. Chen, G. J. Hirasaki, and W. G. Chapman, "Molecular dynamics simulations of NMR relaxation and diffusion of hydrocarbons," in Proceeding of SEG/AAPG/EAGE/SPE Research and Development Petroleum Conference and Exhibition, Abu Dhabi, UAE, 2018.

[57] H. Wang, Z. Lun, C. Lv et al., "Nuclear-magnetic-resonance study on mechanisms of oil mobilization in tight sandstone reservoir exposed to carbon dioxide," in Proceeding of SPE Improved Oil Recovery Conference, SPE paper SPE-179554PA, Tulsa, OK, USA, April 2017.

[58] T. Chen, Z. Yang, Y. Luo et al., "Evaluation of displacement effects of different injection media in tight oil sandstone by online nuclear magnetic resonance," Energies, vol. 11, no. 10, pp. 2836-2852, 2018.

[59] P. Xiao, C. Lv, R. Wang et al., "Laboratory study heterogeneity impact on microscopic residual oil distribution in tight sandstone cores during $\mathrm{CO}_{2}$ immiscible flooding," Energy Sources Part A: Recovery, Utilization \& Environmental Effects, vol. 41, no. 23, pp. 2895-2905, 2019.

[60] J. Cao, Y. Liang, Y. Masuda et al., "Molecular simulation of methane adsorption behavior in kerogen nanopores for shale gas resource assessment," in Proceeding of International Petroleum Technology Conference, Beijing, China, March 2019.

[61] D. Makimura, M. Kunieda, Y. Liang, T. Matsuoka, S. Takahashi, and H. Okabe, "Application of molecular simulations to CO2-EOR: phase-equilibria and interfacial phenomena," in Proceeding of International Petroleum Technology Conference, Bangkok, Thailand, November 2011.

[62] K. Mohammad, T. B. Ali, J. R. Hansel, and M. Valera, "Enhanced oil recovery of shale oil: a molecular simulation study," in Proceeding of SPE/AAPG/SEG Unconventional Resources Technology Conference, Denver, TX, USA, 2019.

[63] M. Guo, A molecular simulation study on adsorption and flow characteristics of tight oil, Master Degree Thesis, China University of Petroleum (East China), 2018.

[64] N. Okamoto, Y. Liang, S. Murata, T. Matsuoka, T. Akai, and S. Takagi, "Slip velocity and permeability of gas flow in nanopores for shale gas development," in Proceeding of SPE Asia Pacific Unconventional Resources Conference and Exhibition, Brisbane, Australia, November 2015.

[65] X. Duan, Z. Hu, N. Shao et al., "Establishment of a new slip permeability model of gas flow in shale nanopores based on experimental and molecular dynamics simulations studies," Journal of Petroleum Science and Engineering, vol. 193, article 107365, 2020.

[66] Z. Zhu, C. Fang, R. Qiao, X. Yin, and E. Ozkan, "Experimental and molecular insights on mitigation of hydrocarbon sieving in Niobrara shale by CO2 huff ' $n$ ' puff," in Proceeding of SPE Annual Technical Conference and Exhibition, SPE Paper SPE196136-PA, Calgary, Alberta, Canada, September-October 2019.

[67] A. Takbiri-Borujeni, M. Kazemi, S. Liu, and Z. Zhong, "Molecular simulation of enhanced oil recovery in shale," Energy Procedia, vol. 158, pp. 6067-6072, 2019.

[68] T. Fang, Y. Zhang, Y. Yan, Z. Wang, and J. Zhang, "Molecular insight into the oil extraction and transport in $\mathrm{CO} 2$ flooding 
with reservoir depressurization," International Journal of Heat and Mass Transfer, vol. 148, article 119051, 2020.

[69] Z. Sun, X. Li, W. Liu, T. Zhang, M. He, and H. Nasrabadi, "Molecular dynamics of methane flow behavior through realistic organic nanopores under geologic shale condition: pore size and kerogen types," Chemical Engineering Journal, vol. 398, article 124341, 2020.

[70] T. Zhou, X. Liu, Y. Wang, C. Chun, and C. Gai, "Experiments of $\mathrm{CO}_{2}$ huff-n-puff process in staged fracturing horizontal wells for developing tight oil reservoirs," Journal of Northwest University (Science \& Technology Edition), vol. 39, no. 2, pp. 125-131, 2017.

[71] P. Nguyen, J. W. Carey, S. V. Hari, and P. Mark, "Effectiveness of supercritical- $\mathrm{CO}_{2}$ and $\mathrm{N} 2$ huff-and-puff methods of enhanced oil recovery in shale fracture networks using microfluidic experiments," Applied Energy, vol. 230, pp. 160-174, 2018.

[72] D. Alfarge, M. Wei, and B. Bai, " $\mathrm{CO}_{2}$-EOR mechanisms in huff-n-puff operations in shale oil reservoirs based on history matching results," Fuel, vol. 226, pp. 112-120, 2018.

[73] L. Li, Y. Du, and J. Sheng, "Investigation of gas penetration depth during gas huff-n-puff EOR process in unconventional oil reservoirs," in Proceeding of SPE Canada Unconventional Resources Conference, SPE Paper 189804-MS, Calgary, Alberta, Canada, March 2018.

[74] Q. Wang, R. Jiang, Y. Cui, and J. Yuan, "Pre-Darcy flow behavior of $\mathrm{CO}_{2}$ huff-n-puff development in Fuyu tight formation: Experiment and numerical evaluation," Journal of Petroleum Science and Engineering, vol. 186, article 106773, 2020.

[75] M. Chen, L. Cheng, R. Cao, C. Lv, J. Wu, and H. Liu, "A pore network model for studying boundary layer effect on fluid flow in tight formation," in Proceeding of the SPE Annual Caspian Technical Conference and Exhibition, Baku, Azerbaijan, November 2017. 